\title{
ACOTACIONES AL ESTUDIO DE CARMEN CHINCHILLA SOBRE LAS SOCIEDADES PÚBLICAS Y LA RESPONSABILIDAD POR SUS DEUDAS
}

\author{
MERCEDES FUERTES \\ Universidad de León \\ mercedes.fuertes@unileon.es
}

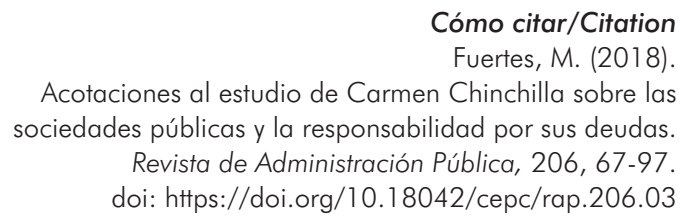

\section{Resumen}

Explica la autora, por un lado, su opinión sobre cuándo debe trasladarse la responsabilidad por las deudas de una sociedad pública a la Administración matriz, así como la necesidad de exigir la debida responsabilidad contable y patrimonial a los miembros del Consejo de Administración. Por otro, admite la existencia de una personalidad jurídica separada de las sociedades públicas y la mixtura del régimen jurídico aplicable. Régimen jurídico que debe preservar algunos criterios de derecho público pero que ha de mantener en todo caso una indispensable esencia mercantil.

\section{Palabras clave}

Sociedades públicas; grupo de sociedades; personalidad jurídica; régimen jurídico de las sociedades públicas; responsabilidad por las deudas sociales.

\section{Abstract}

On the one hand, the author explains her opinion about when the parent Administration should pay public company's debts, as well as the need to demand proper accounting and patrimonial responsibility from the members of the management board. On the other hand, she admits that the public companies haven a separate 
legal identity and that their legal system is complex. Legal system which should preserve some criteria of public law but which it has in any case an indispensable essence commercial.

\section{Keywords}

Public companies; corporate group; legal personality; specific legal system; liability for company's debts. 


\section{SUMARIO}

I. ¿̇DEBE RESPONDER LA ADMINISTRACIÓN POR LAS DEUDAS DE SUS SOCIEDADES PÚBLICAS? II. LA RESPONSABILIDAD DE LOS MIEMBROS DEL CONSEJO DE ADMINISTRACIÓN. III. LA PERSONALIDAD PÚBLICA: ¿̇UN MERO ESPEJISMO? IV. UN RÉGIMEN JURÍDICO COMPLEJO, PORQUE COMPLEJO ES AHORA EL ORDENAMIENTO: 1. Sobre la responsabilidad patrimonial. 2. Sobre el régimen de personal. 3. El régimen de los bienes y del patrimonio de las sociedades. 4. Los órganos societarios. 5. ¿̇Cuál es el interés preferente? 6. El régimen de contratación. V. EPÍLOGO.

El número 203 de esta revista acoge un interesante estudio de la profesora Carmen Chinchilla: «Las sociedades mercantiles públicas. Su naturaleza jurídica privada y su personalidad jurídica diferenciada: ¿`ealidad o ficción?». Quienes hayan leído el texto saben que repasa el régimen jurídico de las sociedades públicas para preguntarse si realmente es tan diverso al de otros organismos públicos y si ha de admitirse o no una auténtica personalidad jurídica separada. Y ello lo suscita porque despliega sobre la mesa de análisis un problema capital, a saber: ¿debe responder la Administración de las deudas societarias?

La pregunta es bien atractiva porque sabemos que no es infrecuente que se presenten tales peticiones ante la Administración matriz e, incluso, que en muchas ocasiones esta las asuma. La crisis económica afectó de manera especial al sector público ${ }^{1}$ y no solo estimuló un régimen drástico de

1 Muchas son las certeras contribuciones que han llamado la atención e ilustrado sobre estos relevantes cambios. Cito como buen ejemplo solo algunos trabajos (discúlpenme quienes no aparezcan porque, por un lado, pretendo solo recoger una muestra y, por otro, algún desliz sin duda habré cometido ante tanta producción científica): A. Embid (2009), El Derecho de la crisis económica, Zaragoza: PUZ; F. Sosa Wagner y M. Fuertes (2011), Bancarrota del Estado y Europa como contexto, Madrid: Marcial Pons; L. Cosculluela (coord.) (2012), Crisis económica y reforma del régimen local, Cizur Menor (Navarra): Aranzadi; A. Blasco Esteve (coord.) (2012), El Derecho de la crisis económica. Transparencia y sector público, Madrid: INAP; L. Martín Retortillo (2012), «Crisis económica 
adelgazamiento con el fin de parar la desbocada procreación de sociedades públicas $^{2}$, sino que también reclamó resolver los saldos rojizos que muchas cuentas y balances presentaban. Si esos números ensangrentados quedan lavados por el presupuesto de la Administración matriz: ¿cómo se puede mantener la existencia de una personalidad jurídica distinta y separada? Es más, ¿es tan diverso el régimen jurídico del que han de seguir los organismos públicos? Estos interrogantes son los que están en la tramoya del trabajo de la profesora Chinchilla y a los que responde dando su opinión con valentía.

He considerado, no obstante, que podría ensayar una breve acotación a ese estudio. Una técnica bien conocida por los juristas que no ha de confundirse ni con las glosas exegéticas ni mucho menos con los barrocos comentaristas que enmarcaron tantos textos romanos. No pretendo reinterpretar ni mucho menos envolver en una disquisición dialéctica el trabajo de Carmen Chinchilla. Mis acotaciones constituyen consideraciones propias y en su forma de expresión han bebido en otras tradicionales fuentes. Quizás sea la más conocida las acotaciones que hizo Napoleón al Principe de Maquiavelo³. Me

y transformaciones administrativas", Revista Española de Derecho Administrativo, 153, págs. 89 y ss.; M. Cueto (2014), "Crisis económica y Administración pública», RVAP, 99-100, págs. 1053 y ss.; J. L. Piñar Mañas (dir.) (2016), Crisis económica y crisis del estado de bienestar : el papel del derecho administrativo. Actas del XIX Congreso Ítalo-Espanol de Profesores de Derecho Administrativo, Madrid: Reus; A. Ezquerra Huerva (coord.) (2016), Crisis económica y derecho administrativo una visión general y sectorial de las reformas implantadas con ocasión de la crisis económica, Cizur Menor (Navarra): Aranzadi.

2 Tras el conocido informe de la Comisión para la reforma de la Administración (CORA) se han publicado muchos documentos que difunden las medidas ejecutadas, así como los resultados obtenidos que son de libre acceso a través de la sede electrónica del Ministerio de Hacienda y Función Pública. A los efectos que ahora me interesan, la Oficina para la ejecución de la reforma de la Administración (OPERA) ha resaltado que en los últimos años se ha reducido en más de dos mil trescientas las entidades del sector público, lo que ha generado un ahorro superior a los tres mil millones de euros. Contamos igualmente con la relevante información que facilita ese Ministerio del inventario de todos los entes del sector público (INVESPE). Véase también E. Montoya Martín (2012), «Reflexiones sobre el sector público instrumental en un contexto de crisis económica: la inaplazable hora de la racionalización», en Actas del VII Congreso de la Asociación española de Profesores de Derecho Administrativo, Madrid: INAP, págs. 15 y ss; y A. Boto Álvarez (2016), «La reordenación de las estructuras administrativas como mecanismo de reducción del gasto público, tendencias globales», en Crisis económica y Derecho Administrativo..., cit., págs. 143 y ss.

3 Junto a la clásica conferencia de J. Garrigues (1970), «Acotaciones de un jurista a la reforma de la empresa», recuerdo la distendida obra de W. Fernández Flores (1970), Acotaciones de un oyente, Madrid: Prensa Española. 
impulsa, además, otra clara intención: provocar un eco de tal estudio. Se escribe mucho y no quisiera que ante tanta publicación pasara desapercibido este excelente trabajo.

A diferencia del guion que sigue la profesora Chinchilla, consistente en explicar primero las cuestiones generales del régimen jurídico y la personalidad separada, para después abrir el interrogante práctico de quién paga las deudas, caminaré en sentido inverso, esto es, atenderé primero a la responsabilidad por las deudas de las sociedades públicas para apuntar mis consideraciones sobre la personificación pública y algunas matizaciones relativas al régimen jurídico de tales sociedades.

\section{I. ¿̇DEBE RESPONDER LA ADMINISTRACIÓN POR LAS DEUDAS DE SUS SOCIEDADES PÚBLICAS?}

Para dar respuesta a esta pregunta, recuerda Carmen Chinchilla muchos pronunciamientos judiciales mostrando que han sido distintos los criterios utilizados por los tribunales atendiendo a las diversas circunstancias en cada conflicto. Y, apoyada en la previa argumentación que ha defendido sobre el peculiar régimen jurídico de las sociedades públicas frente a las compañías mercantiles, ofrece con coraje su criterio: admitir la responsabilidad subsidiaria de la Administración por las deudas societarias que solo se desplazaría si existieran elementos relevantes de una gestión ciertamente autónoma en la compañía pública.

Y aquí empiezan mis acotaciones.

Es la primera que, aun cuando existen muchos pronunciamientos judiciales, sí se advierten algunos hilos que enhebran las soluciones con criterios similares. Así, es más frecuente encontrar condenas a los ayuntamientos a satisfacer las deudas sociales cuando sabemos que la junta general es el Pleno municipal o que muchos consejos de administración se integran por concejales y funcionarios locales. Pero fuera de estos casos, trasladar la responsabilidad no es tan común ${ }^{4}$.

La segunda acotación deriva del régimen general del derecho de grupos, ámbito jurídico donde se han analizado estos problemas para proteger a los acreedores de las sociedades mercantiles.

4 Recoge algunas significativas resoluciones J. A. Recuerda Girela (2012), «La aplicación de la doctrina del levantamiento del velo como técnica para el cobro de deudas de entes del sector público", dentro de la obra que dirige, La morosidad del sector público en el cumplimiento de sus obligaciones, Madrid: Civitas, en especial, a partir de la pág. 695. 
Hace años que ya llamé la atención sobre los riesgos jurídicos e, incluso, democráticos en la actuación de los grupos de sociedades públicas 5 . Ahora vuelvo a invocar ese régimen jurídico de los grupos societarios con la finalidad de recordar que existen algunos criterios generales para atender al problema del pago de las deudas.

Porque también el universo mercantil muestra empresas que influyen en otras compañías: controlan sus decisiones, facilitan las transacciones de activos, el pago de dividendos, la asunción de nuevas obligaciones, en fin, realizan operaciones más o menos arriesgadas que pueden disminuir el patrimonio de las descendientes o afectar a su solvencia. La existencia de tales situaciones permite preguntar si, ante el incumplimiento de sus obligaciones, pueden los acreedores dirigirse al grupo para que, bien la dominante, bien otras sociedades, satisfagan las deudas.

La propuesta de código de sociedades que se redactó en España hace años acogía la responsabilidad subsidiaria de la sociedad matriz cuando se hubiera hecho constar en las relaciones negociales la pertenencia a un grupo o se dedujera de la publicidad existente ${ }^{6}$. Pero, como sabemos, no ha prosperado tal iniciativa ${ }^{7}$. Es más, incluso se derogó el art. 8 de la Ley de defensa de la competencia de 1989, que establecía la corresponsabilidad de la sociedad dominante con relación a las conductas prohibidas que realizaban por indicación las sociedades del grupo. Hoy la responsabilidad conjunta está matizada en el art. 73 de la Ley vigente de $2007^{8}$.

5 Constituyó mi segundo ejercicio en el concurso público para obtener la habilitación y poder optar a una plaza de catedrático de Universidad y que luego publiqué en parte en la monografía Grupos públicos de sociedades, Madrid: Marcial Pons, 2007.

6 Recoge interesantes consideraciones en este punto J. M. Embid Irujo (2012), «Ante la regulación de los grupos de sociedades en España», Revista de Derecho Mercantil, 284, págs. 25 y ss.

7 Carece el derecho español vigente de una regulación sistemática de los grupos. Se atiende, lógicamente, a los grupos en decenas de leyes, pero no hay una regulación sistemática que acoja los múltiples problemas de las relaciones internas y externas. En relación al asunto que ahora interesa, señalo que en otros ordenamientos jurídicos se ofrecen soluciones diversas. Mientras en Alemania tanto la sociedad dominante como el grupo concertado asumen las deudas de las sociedades dependientes (no hay que olvidar que siempre existe un contrato previo de dominación o concertación), los códigos portugués e italianos establecen sistemas mixtos en los que debe analizarse la concreta gestión social y empresarial de los administradores y los beneficios de la sociedad dominante.

8 Otra situación de corresponsabilidad establece la legislación mercantil, a saber, el régimen aplicado a la sociedad que deviene unipersonal en el art. 14 del texto refundido 
La carencia de una regulación sistemática ha sido salvada por los tribunales que han precisado relevantes criterios. Así, algunas sentencias admiten esa transmisión de responsabilidad en los grupos de sociedades porque se advierte una "confusión de personalidades» o la existencia de una auténtica "comunidad de gestión, intereses y beneficios». También se ha atribuido la responsabilidad solidaria a todas las empresas del grupo porque "puede entenderse que ha existido una vinculación más o menos explícita de la misma como garante, o bien cuando con sus propios actos ha creado una apariencia generadora de confianza para los terceros que contratan con las sociedades filiales»?.

Sin embargo, otros muchos pronunciamientos restringen esa comunicación de la responsabilidad ${ }^{10}$.

Pero, sobre todo, lo que interesa saber es que la doctrina mercantil discute y critica lo que se podría convertir en la práctica en el «ilimitado derecho de recuperar los créditos» ${ }^{11}$. Tal generalización quebraría un pilar esencial del derecho societario, la responsabilidad individual de cada sociedad que, teniendo reconocida una personalidad jurídica propia, poseyendo un patrimonio separado, actúa y se obliga en el tráfico mercantil. Porque, si ante el impago de las deudas por una sociedad siempre cuenta el acreedor con la adicional garantía de los patrimonios de los integrantes del grupo, ¿dónde queda el régimen básico de las relaciones entre la sociedad y sus socios? ¿Para qué se ha

de la Ley de sociedades de capital (véase también la sentencia del Supremo de 19 de julio de 2016, TS:2016:3631) y que, en resumen, prevé la responsabilidad personal, ilimitada y solidaria de ese único socio ante las deudas contraídas si no se inscribe en el plazo de seis meses en el registro mercantil. Sin embargo, no cabe invocarla, pues carece de elementos de similitud o analogía.

9 Tales términos son utilizados por la sentencia del Supremo de 4 de junio de 2002 (TS:2002:4028), al analizar la intromisión ilegítima de varias empresas de comunicación pertenecientes al mismo grupo ante una demanda en defensa del honor. Entre las últimas sentencias que confirman este criterio puede leerse la del Supremo de $25 \mathrm{de}$ mayo de 2005 (TS:2005:3384), que condena de manera solidaria a varias sociedades al pago de material informático adquirido por otra. Recuerdan otros muchos pronunciamientos judiciales anteriores C. Boldó Roda (2006) en su imprescindible obra Levantamiento del velo y persona juridica en el Derecho privado español, Cizur Menor (Navarra): Aranzadi, págs. 390 y ss., y J. M. Embid Irujo (1998), «Protección de acreedores, grupo de sociedades y levantamiento del velo de la personalidad jurídica», Revista de Sociedades, 11, págs. 363 y ss.

10 Entre las últimas sentencia que he conocido recuerdo las del Supremo de 10 de marzo de 2005 (TS:2005:1500) y de 19 de abril de 2007 (TS:2007:2368).

11 Sirva, por todas, las ilustrativas consideraciones de C. Paz-Ares (2016), «Uniones de empresas y grupos de sociedades", en la obra colectiva Lecciones de Derecho Mercantil, Madrid: Civitas, págs. 621 y ss. del volumen I. 
separado un patrimonio y se ha identificado una nueva personificación a la que se imputan derechos y obligaciones?

Esta es la preocupación en el ámbito mercantil, una preocupación similar a la que mantenemos en la órbita del derecho público. Y aquí se abren los interrogantes: ¿por qué hemos de cambiar tales consideraciones cuando la sociedad está en la órbita de un grupo público? ¿Existen, como en otros aspectos que sabemos, matices derivados del régimen de derecho administrativo?

A mi juicio, no deberían existir especialidades en el régimen jurídico aplicable cuando la sociedad deudora es pública. Como insistiré más abajo, defiendo su propia personalidad, así como la igualdad de régimen jurídico en la plaza del mercado. Las sociedades mercantiles, públicas o privadas, han de responder de las obligaciones y prestaciones que contraigan, de sus deudas y de sus créditos. No deberían considerarse en todo caso protegidas por la ayuda de otro patrimonio público al que recurrir, pues ello distorsionaría la competencia en el mercado. Porque admitir sin más la comunicación de esa responsabilidad contractual al organismo o Administración pública matriz diluye la identidad de la sociedad.

Es más, si una sociedad pública se desliza hacia una crisis empresarial podrá encauzarse su situación a través del procedimiento concursal. Cosa que está ocurriendo ${ }^{12}$.

Recordemos que el deseo de reconocer una personalidad jurídica propia, la gestión de un patrimonio separado, la llevanza de una contabilidad específica, un mejor análisis de la actividad empresarial, el reparto de competencias y, en consecuencia, de sus responsabilidades... son, entre otros, argumentos que justifican la fecundación de una nueva personificación con capacidad jurídica y de obrar para asumir sus propios compromisos y obligaciones sin trasladar-

12 Dio noticia ya de algunos autos de juzgados de lo mercantil C. Muńoz Gil (2012), «Sociedades públicas: insolvencia y responsabilidades», Diario La Ley de 11 de julio de 2012. Importantes precisiones y propuestas realizan I. Fernández Torres (2015), El concurso de las entidades públicas y sus contratistas, Madrid: Civitas; I. del Guayo Castiella (2004), Sector público empresarial e instituciones paraconcursales, Madrid: Marcial Pons; así como E. García Ruiz (2013), en su trabajo «Insolvencia y concurso de las sociedades mercantiles de control público», Revista de Derecho concursal y paraconcursal, 18, págs. 301 y ss. Mucho interés tiene también el trabajo de I. Calatayud Prats (2012), «Sociedades locales, servicio público e insolvencia», dentro del libro colectivo dirigido por L. Cosculluela y L. Medina, Crisis económica y reforma del régimen local, Madrid: Civitas, págs. 347 y ss., donde muestra con claridad las tensiones y contradicciones existentes cuando sociedades municipales que prestan servicios públicos caen en insolvencia y defiende con valentía que no debería prestarse mediante estas fórmulas algunos servicios municipales. 
los sin mayor consideración a la protectora «mamá Administración». Porque, si esto no se defiende, ¿para qué se creó una nueva personificación?

Sabemos que en el ámbito público resulta exigencia inexcusable que la personificación adopte necesariamente una forma de responsabilidad limitada (art. 166 LPAP, las leyes de Hacienda de las distintas comunidades autónomas y el art. 85 ter LRL). Si tan lógica limitación es la que impone la ley con el fin de contener las pérdidas, ¿cómo puede luego trasladarse sin mayores cautelas otras responsabilidades a la Administración?

En todo caso, como no hay dogmas rotundos, también asumo que, ante especiales circunstancias, pueda analizarse el traslado de esa responsabilidad. Es decir, que es posible mantener criterios similares a los que se aplican a los grupos de sociedades privados y, así, ante circunstancias muy específicas y concretas, podrá abatirse el valladar que supone una personificación separada para trasladar las deudas. Así, por ejemplo: ante la evidencia de un abuso de la conformación de una personificación, la coincidencia de la identidad de las personas que integran el consejo de administración societario con el gobierno municipal, circunstancias que confirmen una firme dirección de la Administración u organismo matriz a través de directrices vinculantes, además de aquellas otras situaciones en que está acreditada una actuación concurrente o unas instrucciones por parte de la Administración matriz ${ }^{13}$.

Es cierto que la tendencia a trasladar la responsabilidad resulta fácil ante una sociedad pública porque se conoce su filiación y está el atractivo imán de la existencia de la red protectora de un patrimonio público. Pero ello debe alertarnos y levantar cautelas que protejan los dineros públicos. Y es aquí donde se abre otro interrogante porque el peligro de la solvencia de las sociedades públicas, de su descapitalización, de la desprotección de los acreedores, no son hipótesis insólitas. En la práctica muchos desequilibrios económicos se han subsanado con más aportaciones públicas a fondo perdido, cesiones gratuitas de bienes, compensando las pérdidas, ampliando el capital, otorgando préstamos y financiaciones extraordinarias, ventajas financieras, ayudas públicas directas u otros beneficios. Sin embargo, ante pérdidas cuantiosas, ante una administración negligente: ¿no hay instrumento para reaccionar y ha de acudirse siempre, al final, a la caja pública de la Administración matriz? ¿De nada responden los gestores de esas sociedades públicas? Tales interrogantes merecen otro epígrafe.

13 Precisó tempranamente estas situaciones S. Muñoz Machado (1998), La responsabilidad civil concurrente de las Administraciones públicas (y otros estudios sobre la responsabilidad), Madrid: Civitas, 2a ed. 


\section{LA RESPONSABILIDAD DE LOS MIEMBROS DEL CONSEJO DE ADMINISTRACIÓN}

Las sucesivas reformas de la legislación mercantil han ido precisando la responsabilidad de los administradores porque se trata de un asunto capital del que pende la confianza en las relaciones jurídicas y económicas. No es este el lugar para recordar la normativa general que perfila las responsabilidades «sociales» e «individuales». A los efectos que ahora me interesan, recuerdo solo que los acreedores pueden dirigirse contra los propios administradores sociales de manera subsidiaria, si no lo han hecho la junta o los accionistas, "cuando el patrimonio social resulte insuficiente para la satisfacción de sus créditos» ${ }^{14}$.

Es cierto que la Ley de patrimonio de las administraciones públicas, así como algunas leyes autonómicas, exoneran de responsabilidad a los miembros de los consejos de administración de las sociedades públicas cuando hayan seguido las instrucciones remitidas por el ministro u órgano autonómico competente (art. 179 LPAP) ${ }^{15}$. Pero hay que delimitar el trazo de ese círculo de exoneración. En primer lugar, porque solo se pueden impartir instrucciones de manera excepcional y con la debida justificación. Así lo señalan las leyes (art. 178 LPAP). Y es lógico. Si se configura una mercantil pública porque se quiere flexibilizar la actuación de determinadas funciones y se desplaza tal gestión de los órganos administrativos internos a otra personificación con su consejo, serán esos vocales con sus conocimientos y experiencias los que lleven la gestión de la compañía. Para esperar órdenes e instrucciones, no se dota de autonomía a un servicio público. Se mantiene una gestión indiferenciada dentro de las dependencias administrativas y se sigue el clásico esquema de jerarquía.

14 Véase el art. 240 del texto refundido de la Ley de sociedades de capital (Real Decreto Legislativo de 2 de julio de 2010) y, entre los muchos trabajos existentes, me permito citar solo los de A. Campuzano (2015), «La acción social de responsabilidad», dentro de la obra colectiva Gobierno corporativo: la estructura del órgano de gobierno y la responsabilidad de los administradores, Cizur Menor (Navarra): Aranzadi, págs. 767 y ss. y A. B. Campuzano (2016), «La acción social en el sistema de responsabilidad de los administradores de las sociedades de capital», en la obra colectiva coordinada por A. Emparanza y J. M. Embid, Las nuevas obligaciones de los administradores en el gobierno corporativo de las sociedades de capital, Madrid: Marcial Pons. Alude a esta cuestión la sentencia de la Audiencia Provincial de Ciudad Real de 22/2015, de 28 de enero (APCR:2015:111).

15 Así, por ejemplo, en Castilla y León (disp. adic. 8a de la Ley de patrimonio de 26 de octubre de 2006) y en Navarra (art. 112 de su Ley de patrimonio de 4 de abril de 2007). 
Los consejeros han sido designados para adoptar decisiones y son, en consecuencia, responsables de la marcha de la compañía. Hay que ser rigurosos y serios con las designaciones recibidas.

En consecuencia, solo ante situaciones excepcionales, que pueden existir, el ministro u órgano competente puede enviar «instrucciones». Porque puede interesar desde el Ministerio la participación en otras sociedades, la escisión de activos u otras decisiones relevantes y que tienen cierta impronta "política". De ahí que, en estos casos excepcionales, donde tal decisión societaria procede de una voluntad política, se establece la exoneración de responsabilidad de los consejeros.

En el resto de los casos, así como en las sociedades municipales donde rige el régimen de responsabilidad de los administradores de las sociedades de capital, responderán los consejeros de manera solidaria por todos aquellos actos $\mathrm{u}$ omisiones contrarios a la ley, a los estatutos o a los deberes inherentes a su cargo cuando haya intervenido dolo o culpa - esta se presume si hay infracción legal o estatutaria- e, incluso, aunque el acto lesivo haya sido autorizado o ratificado por la junta general que, como sabemos, es el pleno corporativo (art. 236 y ss. del texto refundido de la ley de sociedades de capital) ${ }^{16}$.

En conclusión, antes de acudir al «inagotable» presupuesto de la Administración matriz, ha de analizarse la actuación de los consejeros y, en su caso, exigirles la correspondiente responsabilidad. Una responsabilidad que, en primer lugar, ha de encauzarse a través del derecho público, esto es, la responsabilidad contable y, de manera subsidiaria, podrán también reclamarla los acreedores como establece la legislación mercantil ${ }^{17}$.

Hace años que el Tribunal de Cuentas despliega una relevante función de fiscalización y enjuiciamiento con el fin de dirimir y, en su caso, exigir responsabilidades contables a tantas autoridades, funcionarios y administradores de empresas públicas que incumplen las mínimas reglas de cuidado de los caudales públicos y han originado pérdidas societarias (arts. 49 y ss. de la Ley de funcionamiento del Tribunal de Cuentas). Del mismo modo que contamos con la acción de regreso contra las autoridades y funcionarios que actuaron con dolo o negligencia grave y generaron unos daños que han dado lugar al reconocimiento de responsabilidad patrimonial, así también ha de perseguirse a los gestores de caudales públicos que originan un grave menoscabo en el pa-

16 Mas precisiones pueden verse en F. Sosa Wagner (2008), La gestión de los servicios públicos locales, Madrid: Civitas, $8^{\mathrm{a}} \mathrm{ed}$.

17 Dejo de lado la exigencia de responsabilidad penal, porque se trata de actuaciones más graves, pero hay que recordar que la Sala de lo Penal del Supremo ha reconocido el delito de malversación de caudales públicos en el ámbito de una sociedad pública (Sentencia de 7 de octubre de 2014, TS: 2014: 3831). 
trimonio societario. Predicar que las lesiones en el ámbito del derecho público pueden encontrar una cómoda cobertura de la caja común no debe suponer que los responsables directos del desaguisado queden inmunes a cualquier reclamación. De la exigencia de responsabilidad depende el buen funcionamiento del Estado de derecho.

Mi tesis es que, ante elevadas deudas de una sociedad pública, habrá de analizarse la responsabilidad de los consejeros: si han originado grandes pérdidas, un menoscabo del patrimonio de esa sociedad pública, si no han administrado con rigor esos caudales públicos, si la gestión ha sido absolutamente inadecuada, muy cuestionable, si las inversiones eran arriesgadas e injustificadas, si se advierten irregularidades graves, si han realizado pagos indebidos, si se han desenvuelto con negligencia, si han gestionado ese patrimonio de manera arriesgada, si hay descubiertos o alcances... Advertida su responsabilidad, deberán indemnizar los consejeros tales perjuicios ${ }^{18}$.

Y si la Administración no les exige responsabilidad alguna, podrán dirigirse los acreedores frente a los consejeros para el cobro de sus créditos, como reconoce la legislación mercantil.

Pero volvamos al interesante trabajo de la profesora Carmen Chinchilla.

\section{LA PERSONALIDAD PÚBLICA: ¿̇UN MERO ESPEJISMO?}

Uno de los relevantes argumentos de Carmen Chinchilla para justificar su tesis de trasladar las deudas societarias a la Administración matriz es que la atribución de la personalidad jurídica a las sociedades tiene un mero carácter instrumental. Recuerda con rigor pronunciamientos del Constitucional y del

18 Hay ya importantes precisiones doctrinales sobre este régimen jurídico a las que me remito. Recuerdo ahora solo a J. A. Fernández Ajenjo (2011), El control de las Administraciones públicas y la lucha contra la corrupción, Madrid: Civitas, en especial a partir de las págs. 400 y ss.; el trabajo de J. Moreno Vivas (2017), «Empresas públicas», dentro de la obra colectiva dirigida por A. Betancor Corrupción, corrosión del Estado de Derecho, Madrid: Civitas, págs. 299 y ss.; el ilustrativo artículo de G. A. Sánchez Lerma (2014), «Responsabilidad contable y gestión en las sociedades públicas», en $A u$ ditoría Pública, 64, págs. 105 y ss. Conviene saber igualmente que algunas sentencias del Supremo están limitando las facultades de enjuiciamiento del órgano de control, lo que podría conducir a una preocupante impunidad de ciertas autoridades públicas. Analiza dichas sentencias y ofrece interesantes propuestas J. R. Chaves García (2017), «La urgente reconstrucción del enjuiciamiento contable del reintegro por alcance», $E l$ Consultor, 6, págs. 730 y ss. 
Supremo que han destacado tal condición y, en consecuencia, pueden considerarse muy tenues los rasgos de una personalidad jurídica propia.

Tal cualidad no es exclusiva de las sociedades públicas, pues es larga la progresiva complejidad de las estructuras organizativas, tanto en el ámbito privado como en el público, que van originando cascadas o racimos de personificaciones, en otros términos más actuales, "grupos de empresas», como hemos visto ${ }^{19}$.

Como tantas figuras e instituciones jurídicas, la personificación es un «artificio», una ingeniosa idea que ha permitido dar grandes saltos al pensamiento jurídico ${ }^{20}$. Tanto en el ámbito mercantil como en el público. ¿Quién no recuerda el impulso que generó la configuración de la compañía de las Indias orientales ${ }^{21}$ ? ¿Y la convulsión de la recensión de Albrecht ${ }^{22}$ ? Pero ese uso artificial de la personalidad que contiene conocidas ventajas origina, como en tantas manifestaciones humanas, matices, especialidades en el régimen jurídico que ha ido adaptándose a los tiempos. Es más, podríamos hablar de escalas o grados de personificación ${ }^{23}$.

De ahí que Carmen Chinchilla señale algunas debilidades en la construcción de la personalidad jurídica separada de las sociedades públicas. En concreto, alude a la posible gestión directa de servicios públicos, a las previsiones singulares de los llamados "contratos domésticos»; a las reglas de reestructuración del sector público, así como a la imposibilidad de impugnación de actos dentro del sector público. Sin embargo, desde mi punto de vista, tales debilidades no alcanzan a tener el carácter de auténticos «talones de Aquiles».

Tienen más el halo de un cierto «desfallecimiento» que en absoluto supone el fallecimiento de la sociedad mercantil.

19 Sobre estas denominaciones puede verse J. L. Villar Palasí (1994), «Tipología y derecho estatutario de las entidades instrumentales de las Administraciones públicas», en la obra colectiva Administración instrumental. Libro homenaje al prof. Clavero Arévalo, Madrid: Civitas, pág. 178.

20 Por todos, R. Rivero (2017), «El sector público administrativo», dentro de la obra colectiva dirigida por E. Gamero Tratado de procedimiento administrativo común y régimen jurídico básico del sector público, Valencia: Tirant lo Blanch, pág. 2520.

21 Entre otras muchas descripciones, es suficientemente ilustrativo el resumen que hace N. Ferguson (2009), El triunfo del dinero, Barcelona: Debate, pág. 144.

22 F. Sosa Wagner (2005), Maestros alemanes de Derecho público, Madrid: Marcial Pons, $2^{\text {a }}$ ed (pág. 33).

23 Entre otras muchas obras esenciales, sirva el recordatorio al libro canónico de Federico de Castro (1991), La personalidad jurídica, Madrid: Civitas. Apuntó también singularidades relevantes G. Ariño (1971), Sobre la personalidad jurídica en el Derecho público, Madrid: ENAP. 
Las singularidades que explica Carmen Chinchilla y que muestran que, en ocasiones, esa personalidad separada queda aquietada ante su ascendencia porque es incapaz de suscitar conflicto ante la matriz, puede ser objeto de reestructuración y ha de atender con diligencia los encargos, es común también en el ámbito privado de los grupos societarios.

Y así, la imposibilidad de impugnación concurre también en los entramados de sociedades con filiales y nietas de único socio; lo mismo que las facultades del único accionista para reestructurar su grupo societario. Lo que no implica que no se reconozca la existencia de distintas personificaciones. Solo si existen otras participaciones privadas, si hay una sospecha de fraude en los despidos de los trabajadores u otras situaciones que ha analizado la doctrina y la jurisprudencia, florecen con brillo otros principios jurídicos para difuminar esa personalidad separada y proteger los intereses de terceros ${ }^{24}$.

Es la rica y versátil realidad la que origina que haya que mirar con atención los hilos que mueven a las marionetas de personificaciones. Ya se trate de quien controla todo el capital privado, ya de la Administración matriz.

Me detengo en uno de estos asuntos, a saber, el régimen de los «contratos domésticos». Mantengo todavía la costumbre de utilizar esa expresión frente a «encargos a medios propios», quizás por cierto reconocimiento a la larga configuración jurisprudencial de este régimen jurídico sobre el que muchos hemos pensado ${ }^{25}$.

24 Es suficientemente ilustrativo el trabajo de F. Vicent Chuliá (2011), «Grupos de sociedades y conflictos de intereses», Revista de Derecho Mercantil, 280, págs. 19 y ss.

25 Y ello a pesar de que el primer trabajo aparecido sí recogía esta locución tradicional del derecho espańol. Me refiero al estudio de F. Sosa Wagner (2003), «El empleo de los recursos propios por las Administraciones locales», en el libro colectivo coordinado por $\mathrm{L}$. Cosculluela, Estudios de derecho público económico: libro homenaje al prof. Dr. D. Sebastián Martin-Retortillo, Madrid: Civitas, págs. 1309 y ss; y, a partir de ahí, algunos hemos continuado analizando estos problemas. Así, M. Fuertes (2007: 179 y ss.); F. Sosa Wagner y M. Fuertes (2007), «¿Pueden los contratos quedarse en casa? Polémica europea sobre la contratación in house», La Ley, 3, págs. 1669-1680; J. González García (2007), «Medios propios de la Administración, colaboración administrativa y sometimiento a la normativa comunitaria de contratación», Revista de Administración Pública, 173, págs. 217 y ss.; M. A. Bernal Blay (2008), «Un paso en falso en la interpretación del criterio del control análogo al de los propios servicios en las relaciones in house. Comentario a la STJUE de 19 de abril de 2007», Revista Española de Derecho Administrativo, 137, págs. 115 y ss.; J. J. Pernas García (2008), Las operaciones in house y el Derecho comunitario de contratos públicos: análisis de la jurisprudencia del TJCE, Iustel; B. Noguera (2010), «Los encargos in house en la Ley de Contratos del Sector Público. Especial referencia a los mismos en el ámbito local a la luz de la reciente jurisprudencia comunitaria», Revista de Administración Pública, 182; E. Montoya Martín (2011), «La delimitación de los en- 
A pesar de la contundencia con la que la ley afirma que tales encargos «no tendrán la consideración de contratos», creo que puede afirmarse que tienen la naturaleza de un negocio jurídico ${ }^{26}$. Si el legislador pretendía dejarlos fuera del régimen de contratación pública, hubiera bastado incorporar la precisión «a los efectos de esta Ley». Pero no puede ignorarse su naturaleza negocial. Porque una cosa es que la relación doméstica desplace un procedimiento de concurrencia competitiva, la presentación de una oferta... y otra distinta es la naturaleza jurídica de la relación que se traba entre la Administración y "el medio propio»: afecta a dos patrimonios y despliega una relación rica en derechos y obligaciones.

El hecho de que las sociedades públicas estén incardinadas en una Administración no impide suscribir «negocios jurídicos» dentro de la "casa pública». Del mismo modo que en el ámbito privado se atiende desde antiguo a la figura de los «autocontratos». Es cierto que las reglas que inspiran unas y otras relaciones son diversas porque han de atender a problemas distintos. En el ámbito privado han de cuidarse de manera esencial los conflictos de intereses y que no se perjudique a terceros ${ }^{27}$. En el ámbito público, la normativa se dirige a no falsear la competencia mercantil.

En fin, tales singularidades no me parecen suficientes para negar una personalidad jurídica separada. Se trata, como he escrito, de un mero «desfallecimiento» en situaciones muy específicas.

$\mathrm{Y}$ entramos en otro de los principales argumentos del estudio.

\section{UN RÉGIMEN JURÍDICO COMPLEJO, PORQUE COMPLEJO ES AHORA EL ORDENAMIENTO}

Apunta Carmen Chinchilla la inexistencia de un régimen jurídico acotado y sistematizado con nitidez de las sociedades públicas a pesar de que, a su entender, cuenta el legislador estatal con un título jurídico de competencia,

cargos domésticos: presupuesto para evitar la huida de las grarantías de la contratación pública», en la obra coordinada por F. López Menudo, Derechos y garantías del ciudadano: estudios en homenaje al profesor Alfonso Pérez Moreno, Madrid: Iustel, págs. 859 y ss.

Por todos, conviene siempre acudir a la obra de F. de Castro (1985), El negocio jurídico, Madrid: Civitas, entre otras, pág. 34.

27 Desde el trabajo de Federico de Castro (2003), «El autocontrato en el Derecho privado español», dentro de la recopilación de sus Estudios jurídicos del Prof. de Castro, Madrid: Centro de Estudios Registrales, págs. 3 y ss., son muchas las monografías y artículos que analizan los problemas de esta situación tan utilizada en la representación, las sociedades limitadas, etc. 
como es el de dictar la legislación mercantil. Y es que los preceptos relativos a las sociedades públicas contenidos en las leyes del sector público y del patrimonio solo se aplican a las de carácter estatal.

A mi juicio, parece suficiente teniendo en cuenta la densa normativa mercantil. Resulta ésta una opción respetuosa con la autonomía organizativa que puede derivar en otras precisiones en la legislación autonómica, así como también en los estatutos orgánicos de las administraciones locales.

El deseo que tantas veces manifestamos de unos códigos completos, claros, comprensivos de todo un sector, se estrella contra la realidad de la hipertrofia normativa y la multiplicación de regímenes jurídicos. No es fácil aislar el régimen jurídico de tantos actores de las relaciones jurídicas. Máxime con la catarata de disposiciones que van precisando singularidades, incrementando obligaciones específicas, generando sectores especiales. En este sentido, las sociedades públicas son un buen ejemplo porque pueden saltar a la escena para interpretar muy diversos papeles. Pero es que también nos encontramos con específicas singularidades en múltiples sociedades mercantiles privadas, ya que son muchas las disposiciones que incrementan los requisitos de constitución de algunas compañías, establecen exigencias especiales en sus consejos de administración, así como otras obligaciones en la llevanza de sus cuentas o en su funcionamiento ${ }^{28}$.

Es más, y retorno a las sociedades públicas, hay que tener muy en cuenta la legislación de la Unión Europea fruto de un esforzado procedimiento de acoger las instituciones y perspectivas diversas del derecho de los Estados miembros. Así, por ejemplo, dejando a un lado la complejísima normativa contable que, recordémoslo, tiene su propia concepción de las sociedades públicas $^{29}$, desde nuestra perspectiva jurídico-pública hay que atender a la relevante regulación sobre la transparencia de las relaciones entre las Administraciones y sus empresas que gira sobre el eje de la expresión: «influencia dominante». Una locución esta que, al contar con varios brazos de posibilidades de técnicas de dirección, de control o de vigilancia, puede dar un amplio

28 No es este el lugar de recordar las especialidades y remisiones que realiza el texto refundido de la ley de sociedades de capital de 2 de julio de 2010, ni, sobre todo, los regímenes singulares privados que tienen tantas mercantiles de financiación, de seguros, bancarias, de servicios de inversión, sociedades tecnológicas, laborales... así como las obligaciones de carácter público que han de satisfacer las sociedades cuyo objeto social incide en servicios de interés económico general.

29 Me refiero a las delimitaciones que se recogen en el sistema de cuentas económicas integradas que desde el año 1970 se han ido precisando y que ahora contiene el —si se me permite la expresión- engorroso Reglamento comunitario 549/2013, de 21 de mayo. 
abrazo y acoger en el círculo público a otras sociedades mercantiles y no solo a aquellas cuyo capital pertenece a la Administración pública o esta designa a la mayoría de los vocales de su consejo de administración ${ }^{30}$.

Lógica preocupación genera delimitar esta tenue línea para advertir si una sociedad tiene carácter público o no porque el mismo es el que determinará, como bien sabemos, el régimen jurídico aplicable.

Desde hace años la legislación resuelve esta cuestión recordando que estas sociedades se rigen por el derecho privado salvo en lo que les sea de aplicación la «normativa presupuestaria, contable, de personal, de control económicofinanciero y de contratación ${ }^{31}$.

30 Es sabido que la Ley 4/2007, de 3 de abril, incorporó las modificaciones realizadas a la primera Directiva que atendió a esta necesaria de garantizar la transparencia financiera, salvaguardar las reglas de la competencia y evitar los abusos de posición dominante (Directiva 80/723, de 25 de junio, modificada por la Directiva 2006/111, de 16 de noviembre) y que explicó J. L. Martínez López-Muñiz (1987), «La ampliación del ámbito de aplicación de la Directiva sobre transparencia de las relaciones financieras de las empresas públicas», Noticias de la Unión Europea, 33, págs. 13 y ss. Hoy, este río de información acumula otros afluentes caudalosos dando referencias ambientales, sociales, sobre el gobierno corporativo, etc. y generando un informe integrado exigible ya tras la última modificación de la ley de sociedades de capital mediante el Real Decreto Ley 18/2017, de 24 de noviembre que ha incorporado otras dos directivas europeas (las números 2013/34 y 2014/95 sobre divulgación de información no financiera). Interesantes artículos sobre este informe integrado contiene el número 57 monográfico de la Revista española de control externo que apareció en septiembre de 2017. Muy recomendable es también la lectura de la monografía de E. García Ruiz (2006), La nueva sociedad anónima pública, Madrid: Marcial Pons, que analiza distintos criterios de control para dar su opinión sobre la delimitación de las empresas públicas.

31 Tal expresión, que se encuentra ahora en el art. 113 de la Ley del sector público, es bastante similar a la anterior alojada en la disposición adicional duodécima de la Ley de organización y funcionamiento de la Administración General del Estado de 1997 y que superó la clásica remisión a entrar en la casa del derecho privado y seguir sus normas establecidas desde la aprobación de la ley de entidades estatales autónomas y después en las leyes presupuestarias. Y es que desde esa disposición, las sucesivas leyes presupuestarias han ido estableciendo que las sociedades estatales se regirían "por las normas de Derecho mercantil, civil o laboral, salvo en las materias en las que les sea de aplicación la presente Ley» (así la Ley general presupuestaria de 4 de enero de 1977 y el texto refundido de 23 de septiembre de 1988), abundando más precisiones la reforma de esta Ley de 16 de noviembre de 2003. Sobre las consecuencias de la vigente regulación, puede verse el trabajo de M. L. Gómez Jiménez (2016), «Organización y funcionamiento del sector público institucional. II», dentro de la obra que coordinó 
La legislación local, bien enriquecida por la viva experiencia de las sociedades municipales, recogía la tradicional expresión de que «se regirán íntegramente, cualquiera que sea su forma jurídica, por el ordenamiento jurídico privado» para luego introducir las precisiones: «salvo las materias en que les sea de aplicación la normativa presupuestaria, contable, de control financiero, de control de eficacia y contratación». Hoy, además, la Ley de Haciendas locales ha encendido más focos luminosos de supervisión de estas sociedades públicas ${ }^{32}$.

Parece, pues, que han de atender estas sociedades públicas a las dos esenciales caras de la moneda del derecho que desde tiempo inmemorial diferenciamos para advertir el interés preferente en las relaciones jurídicas, en resumen, si levanta su mirada hacia al bien común o si la baja porque queda reservada a aspectos más privados. Así, la persona societaria parece que se le va un ojo hacia la tendencia propia de su querer, «ser de naturaleza privada», mientras que con el otro no ha de desatender algunas obligaciones derivadas de su estirpe pública. Ello exige cierto esfuerzo de análisis normativo que podría deslizarse en un peligroso estrabismo divergente. Y tal dolencia se debe corregir. Esa doble atención a disposiciones clasificadas como propias de la Administración y normas «privadas» ha de integrarse, igual que hacen nuestros ojos, para dar una visión coherente y sana.

Sabemos que tal complejidad viene motivada, en términos generales, por dos aspectos. El primero, porque cuando la Administración toca con su dedo una institución, figura o relación jurídica, lo trastoca. La Administración es una especie de rey Midas que transforma todo con lo que entra en contacto: sus decisiones tienen un procedimiento y régimen especial; su personal, también; sus bienes, qué decir de sus contratos y así un largo etcétera. Aun cuando quiera participar sin «molestar», sin afectar el régimen jurídico... al final siempre aparece su carácter, un poder forjado y también domeñado durante siglos que se legitima en garantizar el interés público y en cuidar de los dineros públicos. Volveré más abajo sobre esta consideración.

El segundo aspecto que hay que tener en cuenta es la gran tensión que durante décadas viven las sociedades públicas. A mi entender, no se pueden mirar y abarcar tales peculiaridades en el régimen jurídico sin recordar las grandes presiones y conflictos que giran sobre las sociedades públicas. Siguiendo tantas monografías que han ofrecido análisis rigurosos sobre las empresas

H. Gosálbez, El nuevo régimen jurídico del sector público, Madrid: Wolters Kluwer, págs. 285 y ss.

32 Así como los desarrollados en el Real Decreto de 28 de abril de 2017 que precisa numerosos mecanismos de supervisión del sector público local. 
públicas ${ }^{33}$, trato de explicarlo a los sufridos alumnos de los primeros cursos de derecho que se han de enfrentar con el variopinto baile de disfraces del sector público $^{34}$. Conviene, pues, apoyarse en la pértiga de la historia para que desde cierta posición elevada se vislumbre mejor la compleja peculiaridad de este régimen jurídico que sufre de tensiones y ha ido sorteando algunos conflictos.

$\mathrm{Y}$ así es como pueden entenderse tantos cambios y precisiones de los legisladores. Porque hubo un tiempo en que el parto de una sociedad pública otorgaba una especie, si se me permite la licencia, de sexo indubitado porque debía atender al vestuario y actuaciones que ofreciera el «derecho privado». Sin embargo, la necesidad de evitar los abusos ha generado sucesivas modificaciones para ir abrigando a estas empresas con unas mínimas previsiones propias de su linaje público. Hay que evitar la frivolidad de que las «criaturas del

33 Sería bien larga, además de superflua en este momento para los especialistas que leen estas líneas, la cita de los libros monográficos sobre las sociedades públicas. Sin embargo, en este momento no me resisto a rendir un debido homenaje por lo mucho que aprendí de empresas públicas leyendo, entre otros, los Manuales de derecho económico de A. Manzanedo (1970), R. Martín Mateo (1977), S. Martín Retortillo (1988); así como los trabajos más específicos de T. R. Fernández Rodríguez (1965), «Notas para un planteamiento de los problemas actuales de la empresa pública», Revista de Administración Pública, 46, págs. 95 y ss. y (1996), «Empresa pública y servicio público: el final de una época», Revista de Administración Pública, 89, págs. 37 y ss.; A. Pérez Moreno (1969), La forma jurídica de las empresas públicas, Sevilla: IGO; A. Alonso Ureba (1988), La empresa pública. Aspectos jurídico constitucionales y de Derecho económico, Madrid: Montecorvo; G. Ariño Ortiz (1995), «De la empresa pública a la empresa con participación pública: ¿privatización o reforma? Quizás ambas cosas», Revista de Administración Pública, 138, págs. 7 y ss. o (2007), Empresa pública, empresa privada, empresa de interés general. Lecciones retrospectivas, de las que algo se puede aprender, Cizur Menor (Navarra): Aranzadi; J. C. Laguna de Paz (1994), "La empresa pública: formas, régimen jurídico y actividades» en el Libro homenaje al Prof. Clavero Arévalo, Madrid: Civitas, págs. 12 y ss. del segundo tomo; E. Montoya Marín (1996), Empresa pública sometida al Derecho privado, Madrid: Marcial Pons; R. Rivero (1998), Administraciones públicas y Derecho privado, Madrid: Marcial Pons; I. Guayo Castiella (2004), Sector público empresarial e instituciones paraconcursales, Madrid: Marcial Pons, y, entre los últimos, los expresivos trabajos de varios autores que integran la obra colectiva dirigida por F. García Rubio (2011), Estudio sobre las empresas públicas, Madrid: Dykinson.

34 Hace tiempo que F. Sosa Wagner y yo (2008) utilizamos este símil y recordamos la simpática opereta del Murciélago (Die Fledermaus) de Johann Strauss (hijo) para criticar la distinta atribución de jurisdicción de los contratos suscritos por algunas entidades públicas dependiendo exclusivamente de su presupuesto («La ley de contratos del sector público y el murciélago», Actualidad jurídica Aranzadi, 743). 
Estado» se comporten de manera arbitraria fuera de la casa del derecho, de los controles que se han levantado durante décadas para encauzar un razonable ejercicio del poder público y, sobre todo, ha de cuidarse la Hacienda común.

Insisto, a mi juicio, el perpetuum mobile del régimen jurídico de las sociedades públicas ha mostrado la persecución de unos perros pastores que han ido acotando el campo de expansión de ese ganado societario que pretendía corretear y pastar libre por el holgado espacio que ofrece la autonomía de la voluntad y la libertad de los pactos privados. Y así se han cercado dentro de ese amplio pastizal algunos espacios de derecho administrativo. Esto es lo que ha ocurrido en tantos aspectos que recuerda la autora.

En concreto, se detiene con acierto Carmen Chinchilla en el régimen del ejercicio de potestades públicas, los contratos, los bienes, el personal y la responsabilidad. Apunto unas breves acotaciones.

\section{SOBRE LA RESPONSABILIDAD PATRIMONIAL}

Es quizás en este ámbito donde mejor se advierte la notable evolución del régimen jurídico de las sociedades públicas. Ha padecido un giro radical, como de una aguja imantada, hacia el derecho administrativo. Desde el art. 33 de la Ley de régimen jurídico de la Administración del Estado que reconducía la exigencia de responsabilidad a los tribunales ordinarios y, por ello, a las reglas sustantivas del Código Civil, hoy el art. 35 de la Ley del sector público encauza toda responsabilidad al orden contencioso. Una densa prosa declara: la responsabilidad se exigirá siempre siguiendo el régimen propio de la responsabilidad de las Administraciones públicas «incluso cuando concurra con sujetos de derecho privado o la responsabilidad se exija directamente a la entidad de derecho privado a través de la cual actúe la Administración o a la entidad que cubra su responsabilidad». Es decir, la reclamación de tales daños y perjuicios se encuentra amparada por el peculiar régimen que ha generado el derecho administrativo y conocerá el orden contencioso administrativo con independencia de que haya riesgos asegurados o de que hayan concurrido en el origen de los daños otras personas o sociedades privadas. Desde el tradicional sometimiento a las reglas del Código Civil que mantiene el principio de responsabilidad subjetiva y culposa con el consiguiente juicio por el orden jurisdiccional civil se ha trasladado la disputa al orden contencioso, donde se aplicará el sistema garantista de responsabilidad objetiva propio de las administraciones públicas ${ }^{35}$.

35 Analizan esta regulación, entre otros, E. Gamero (2017) en la obra colectiva Tratado de procedimiento administrativo común y régimen jurídico del sector básico del sector 
Si hace décadas la reforma de la ley del procedimiento sometió a los organismos vinculados a las administraciones públicas, incluso en sus relaciones privadas, a un procedimiento administrativo de reclamación ${ }^{36}$, hoy se ha dado el salto para consolidar una unidad de fuero en esta materia. Algo que había sido apuntado en muchas ocasiones ante los continuos conflictos de jurisdicción $^{37}$. En fin, durante años se han dictado muchas sentencias que han condenado al Ayuntamiento y a sus sociedades municipales de manera solidaria por los daños que causan los servicios públicos que gestionaban ${ }^{38}$. Y es que en el ámbito de la prestación de servicios públicos es más frecuente que se involucre a la Administración en los daños que genera la prestación de servicios por un tercero, ya sea concesionario o una sociedad pública ${ }^{39}$.

Esta opción legislativa, a saber, trasladar todas estas cuestiones al ámbito público, evita que una Administración pueda alterar el régimen jurídico de la

público, Valencia: Tirant lo Blanch, págs. 136 y ss.; y M. Pizarro Nevado (2017), «Disposiciones generales, principios de actuación y funcionamiento del sector público» en la obra coordinada por $\mathrm{H}$. Gosálbez, El nuevo régimen jurídico del sector público, cit.

36 Así lo explicaron tras la reforma de la Ley de régimen jurídico, por ejemplo, J. Leguina (1993), «La responsabilidad patrimonial de la Administración, de sus autoridades y del personal a su servicio», en el volumen colectivo por él codirigido, La nueva Ley de régimen jurídico de las Administraciones públicas y del procedimiento administrativo común, Madrid: Civitas, págs. 403 y ss. y L. Martín Rebollo (1994), «La responsabilidad patrimonial de las Administraciones Públicas en España: estado de la cuestión, balance general y reflexión crítica», $D A$, págs. 237-238.

37 Junto a los clásicos tratados y manuales, analizó con rigor los problemas que suscitaba la responsabilidad patrimonial L. Martín Rebollo (1977), en su completa obra $\mathrm{La}$ responsabilidad patrimonial de la Administración en la jurisprudencia, Madrid: Civitas. La imprescindible visión civilista la ha aportado de manera especial la obra de F. Pantaleón. Sirva ahora el recordatorio de sus instructivos trabajos (1988) Responsabilidad civil: conflictos de jurisdicción, Madrid: Tecnos y (1996), «Responsabilidad patrimonial de las Administraciones públicas: sobre la jurisdicción competente», Revista Española de Derecho Administrativo, 91, págs. 403 y ss. En otro lugar, he atendido con detalle a las contradicciones de la jurisprudencia en esos años (2007: 220 y ss.).

38 Así, pueden verse las sentencias del Tribunal Superior de Justicia de Andalucía de 3 de abril de 2000, del Tribunal Superior de Justicia de Galicia de 28 de marzo de 2003 o del Tribunal Superior de Justicia de Murcia de 23 de febrero de 2004.

39 Por ejemplo, este es el fundamento que se esgrime en la sentencia de la Audiencia Provincial de Baleares de 13 de mayo de 1999, ante la exigencia de responsabilidad patrimonial que formula el propietario de un vehículo que se retiró por la empresa municipal que gestiona el servicio de grúa, al entender que estaba abandonado. La sentencia confirma el criterio de declarar la competencia de la jurisdicción contenciosa al entender que había actuado siguiendo órdenes recibidas del Ayuntamiento. 
responsabilidad al personificar la gestión de una función o servicio público ${ }^{40}$. Es cierto que se rompe la aparente coherencia de un régimen jurídico privado, pero impide los conflictos de jurisdicción, así como la confusión del derecho aplicable ${ }^{41}$. Aunque sabemos bien, se mantienen otras tensiones como las que derivan de las diferencias de régimen jurídico si atendemos a los servicios públicos gestionados por un concesionario o una sociedad mixta. Pero zanjar tantas tensiones y evitar las incoherencias requeriría afrontar con mucho vigor la reforma del régimen común de la responsabilidad extracontractual. Empeño que requiere un previo esfuerzo de delimitar bien los diversos entornos, así como la justificación de la compensación en cada situación ${ }^{42}$.

\section{SOBRE EL RÉGIMEN DE PERSONAL}

Espacio este donde también se ha advertido cómo aparece una cierta radiación de los principios propios del derecho público, de la que se han querido ocultar las sociedades públicas alegando los amplios espacios de libertad de contratación que ofrece el derecho privado, ha sido el régimen jurídico del personal. Las primeras afirmaciones que enmarcaban el régimen jurídico mantenían la absoluta aplicación del derecho laboral, lo que derivó en una cierta discriminación entre el personal del sector público ${ }^{43}$. Resulta innecesario comparar

40 En el mismo sentido se ha pronunciado de manera reiterada E. Montoya Marín (1996), entre otros, en su libro Las empresas públicas..., cit. pág. 553 y ss.; así como en mi libro (2007), Grupos públicos de sociedades, págs. 220 y ss.

41 Un ejemplo de la tintura del régimen privado puede verse en la sentencia de la Audiencia Provincial de Valencia de 7 de mayo de 2002 que admitió la exigencia de responsabilidad de la empresa municipal de transportes ante las lesiones de un viajero porque la empresa genera — según este Tribunal- riesgos y obtiene beneficio en la explotación del servicio. Es cierto que, como se ha podido leer unas notas más arriba, rápidamente se modificó este criterio que no vuelve a aparecer en las muchas reclamaciones por lesiones que parece originar el servicio de transporte urbano de Valencia. También matiza el criterio subjetivo la sentencia de la Audiencia Provincial de Madrid de 25 de junio de 2001 mediante una presunción de culpabilidad y la generación del riesgo con el transporte urbano, sin que desaparezca la consideración de la culpabilidad.

42 J. A. García Amado (2011), «Responsabilidad jurídica», Eunomía-Revista en cultura de la legalidad, 1 , págs. 125 y ss.

43 Con rigor se ha denunciado la extensión del personal laboral en el sector público que la regulación vigente recoge ya, como destaca J. A. Fuentetaja (2013), de manera «resignada» (Pasado, presente y futuro de la función pública. Entre la politización y la patrimonialización, Madrid: Coed. FAME - Civitas, pág. 300). Entre las muchas obras que analizan este problema, recuerdo ahora solo la monografía de S. del Saz (1995), 
la seriedad y rigor de algunos procedimientos de selección en el ámbito de la función pública, el escuálido régimen de retribuciones en muchas escalas, el sometimiento a un régimen disciplinario... con la contratación, retribuciones y derechos de los trabajadores de una empresa. Durante muchos ańos la selección del personal de las sociedades públicas no se ha realizado respetando los principios de igualdad, transparencia y publicidad; ni se han atendido a los sustanciales criterios de capacidad, competencia, y mérito. La imitación del régimen de las sociedades privadas no se ha limitado a satisfacer su marco de regulación mercantil, sino que, incluso, se ha llegado a seguir las mismas prácticas en la contratación de parientes, allegados, amigos o simpatizantes para los puestos de alta dirección. En las sociedades privadas, sobre todo en las empresas familiares, eso podrá tener algún sentido, pero no existe ninguna justificación razonable en el ámbito público para ese abuso que conduce al clientelismo político.

Desde la aprobación de la legislación básica relativa al estatuto del empleado público deberán ya las sociedades garantizar que la contratación de su personal ha satisfecho los principios de igualdad, mérito y capacidad a través de procedimientos públicos, abiertos, transparentes, que aseguren la profesionalidad y que respete un cupo de acceso por discapacidad... Lo mismo que respetar los códigos de conducta (disp. adic. primera del Estatuto básico). Igualmente ha de recordarse que tienen también la consideración de «alto cargo" a los efectos de aplicar ese estatuto jurídico los miembros de los consejos de administración de las sociedades públicas ${ }^{44}$.

Sin embargo, advirtamos que se trata solo de salvaguardar esos principios y que, por tanto, queda mucho camino por recorrer antes de reconocer que se respetan las garantías del acceso de la función pública en las empresas públicas. Una prueba es la sentencia del Supremo de 6 de julio de 2016

Contrato laboral y función pública. Del contrato laboral para trabajos manuales al contrato blindado de alta dirección, Madrid: Marcial Pons; el trabajo, entre otros muchos artículos, de M. Sánchez Morón (1999), «Reflexiones sobre las vinculaciones constitucionales en materia de empleo público», Revista Catalana de Derecho Público, 24, págs. 11 y ss., así como su Derecho de la función pública, Madrid: Tecnos, 2016, 9a ed.; los libros sobre función pública de F. Castillo, así como las obras colectivas dirigidas por J. Bermejo (2011), El personal directivo en las Administraciones públicas, Madrid: Civitas o S. Rodríguez-Campos (2014), El empleo público en tiempo de reformas, Madrid: Marcial Pons.

44 Así se establece en el art. 1.2.d) de la Ley 3/2015, de 30 de marzo, reguladora del ejercicio del alto cargo de la Administración del Estado, criterio similar que han seguido muchas leyes autonómicas. Por ejemplo, el art. 1.2c) de la Ley de Castilla y León 3/2016, de 30 de noviembre. 
(TS:2016:3613). Al analizar la cobertura de vacantes restringidas al personal calificado de "fijo discontinuo», además de aquel que ya haya trabajado durante al menos seis meses, declara sin matices la inaplicación de todo el «bloque normativo» del acceso a la función pública a la empresa Tragsa. «Las normas del Estatuto básico del empleado público son inaplicables a las sociedades mercantiles de titularidad pública», han sido sus palabras, que a mí me han dejado sin palabras ${ }^{45}$.

Queda, en consecuencia, una gran labor por realizar para garantizar los principios de derecho público en esas relaciones laborales. Además de evitar que algunas tendencias propias y razonables del mundo privado laboral, como por ósmosis, no falsifiquen los pilares que ha levantado el régimen de la función pública ${ }^{46}$.

\section{EL RÉGIMEN DE LOS BIENES Y DEL PATRIMONIO DE LAS SOCIEDADES}

Recuerda Carmen Chinchilla que la Sala Segunda del Tribunal Supremo considera que el patrimonio de las sociedades públicas tiene la consideración de patrimonio público a los efectos de valorar el delito de malversación de caudales públicos. Cauta previsión dirigida a protegerlo con independencia de las sucesivas titularidades fiduciarias que lo gestionen ${ }^{47}$.

Pero, junto a esta regla de protección, debemos insistir en que su régimen jurídico dependerá de su concreta naturaleza y afectación. Así, es frecuente que gran parte del patrimonio tenga la condición de bienes patrimoniales o de propios, mientras que también son muchos los ejemplos de sociedades públicas a las que se afectan bienes demaniales. Una cesión que suscitó inicialmente en los registros mercantiles alguna confusión porque, sabido es, las aportaciones al capital social se realizan, en principio, a título de propiedad salvo que se indique otra $\operatorname{cosa}^{48}$. Pero como aclaró la doctrina, caben tales

45 Otras sentencias de Tribunales Superiores de Justicia han insistido en esta idea, así como también la del Supremo de 30 de enero de 2017 (TS:2017:542).

46 J. R. Chaves García y B. Quesada (2017), «La expansión desbocada del derecho laboral en la Administración», El Consultor, 17, págs. 2061 y ss.

47 Y así los tribunales penales han dictado sentencias condenatorias como las del Supremo de 14 de febrero (TS:2017:570) o 7 de septiembre de 2017 (TS:2017:3211), que confirman fallos de la Audiencia Nacional. Sepultados han de quedar los pronunciamientos del Supremo que negaba el carácter público de los fondos de las sociedades públicas.

48 Por ejemplo, la Resolución de la Dirección General de los Registros y del Notariado de 12 de diciembre de 1985 . 
cesiones de bienes de dominio público como aportaciones sin que padezca la calificación jurídica ${ }^{49}$.

Es cierto también que, frente a esa claridad doctrinal, el legislador ha forzado algunas situaciones y determinadas entidades públicas mantienen poderes especiales sobre bienes demaniales como han alertado algunos autores ${ }^{50}$. Nos llevaría lejos seguir ahora ese sendero y de ahí que me mantenga en el ámbito del patrimonio de las sociedades públicas; en ellos, ha de defenderse bien una titularidad fiduciaria o bien una cesión de derechos de uso y explotación.

\section{LOS ÓRGANOS SOCIETARIOS}

También son singulares algunas de las reglas que afectan a los miembros de los órganos de administración de las sociedades públicas.

Ya hemos visto la exención de responsabilidad de los vocales del consejo de administración cuando hayan seguido instrucciones del Ministerio de tutela (art. 178 LPAP). Pero, como recordé, tales instrucciones deben producirse de manera excepcional, por lo que ha de tratarse de una situación esporádica y relevante, muestra de que la decisión puede estar trufada de una intencionalidad política, de una estrategia de gobierno de la que no deben hacerse responsables los funcionarios públicos que están en los consejos de administración de las sociedades.

Otra singularidad se refiere a la delimitación de quienes son los «consejeros independientes», esto es, todos aquellos que no estén vinculados a la Dirección general del patrimonio del Estado o al organismo público accionista de la sociedad (art. 140 del Reglamento de la Ley de patrimonio). A mi juicio, tiene sentido tal precisión y no debe exagerarse su relevancia porque en las sociedades públicas no debe existir la tensión entre los «accionistas» — dejemos a un lado las sociedades mixtas públicas - ni tampoco han de acogerse unas reglas especiales para proteger a los «minoritarios» que, entre otras conside-

49 Por todos, F. Sosa Wagner (2008: 176 y ss.).

50 Por todos, las interesantes consideraciones de J. V. González García (1998), La titularidad de los bienes del dominio público, Madrid: Marcial Pons, págs. 186 y ss.; J. A. Santamaría Pastor (2004), «Objeto y ámbito. La tipología de los bienes públicos y el sistema de competencias», en la obra dirigida por C. Chinchilla, Comentarios a la Ley de patrimonio de las Administraciones públicas, Madrid: Civitas, sobre las imprecisiones de la clásica distinción, en especial, págs. 77 y ss.; así como los trabajos de J. M. del Valle (2004), «El patrimonio de las Universidades» y Ma J. Alonso Más (2004), «Régimen patrimonial de determinados organismo públicos», en la obra dirigida por J. F. Mestre Delgado, El régimen jurídico general del patrimonio de las Administraciones Públicas, Madrid: El Consultor, págs. 91 y ss. y 1391 y ss. 
raciones, son las que justificaron la incorporación de estos consejeros en las mercantiles privadas ${ }^{51}$.

Del mismo modo, no entiendo que deba darse especial significado al desplazamiento de la normativa de incompatibilidades de la función pública y que, en consecuencia, pueden nombrarse a funcionarios públicos para llevar la administración societaria (art. 180.2 de la Ley de patrimonio).

En fin, a mi juicio, todas estas singularidades no tienen el suficiente peso para considerar que constituyen un régimen jurídico distinto al de las compañías mercantiles. Responden a la lógica de integrar las diversas disposiciones del ordenamiento jurídico. Han de respetarse las disposiciones mercantiles, si la Administración engendra una sociedad, pero deberá acomodar e interpretar las disposiciones advirtiendo el espíritu y finalidad de las diversas previsiones.

\section{5. ¿̇CUÁL ES EL INTERÉS PREFERENTE?}

Asunto relevante, a mi juicio, es insistir en la preferencia del interés público como leitmotiv de cualquier actuación de estas sociedades públicas frente a la búsqueda del lucro empresarial que mueve toda sociedad de capital por definición.

Sabido es que en la génesis de una sociedad mercantil la Administración ha de justificar de manera adecuada la elección de esa forma jurídica, la iniciativa empresarial pública y los fines públicos que pretendía atender. En el ámbito local, como es sabido, es imprescindible completar un previo expediente en el que se acredite la conveniencia y oportunidad de la iniciativa económica municipal, su "utilidad pública» y el beneficio de sus habitantes ${ }^{52}$.

En consecuencia, ha de insistirse en que las administraciones, al constituir sociedades o participar de manera dominante en otras, no persiguen en primer término la obtención de rentables beneficios empresariales, sino coadyuvar para que se alcancen o faciliten determinados intereses públicos a través de la utilización de esas personificaciones privadas.

51 En este sentido, el artículo de J. M. Garrido García (2006), «Los consejeros independientes", dentro de la obra colectiva Junta general y consejo de administración de la sociedad cotizada, Cizur Menor (Navarra): Aranzadi, págs. 955 y ss. del segundo tomo. Así lo establecen los arts. 86 de la Ley básica de régimen local y 96 del texto refundido de disposiciones de régimen local. Tras las últimas reformas legislativas que persiguen la estabilidad financiera, deberán acreditarse otros extremos como su eficiencia y sostenibilidad (arts. 85 y 85 ter). Este interesante asunto de la iniciativa económica municipal ha sido analizado por muchos autores. Sirva ahora solo el recordatorio de los trabajos de T. de la Quadra Salcedo (1999), Corporaciones locales y actividad económica, Madrid: Marcial Pons. 
Esta prioritaria atención al fin público no supone ninguna quiebra del derecho societario. Es cierto que el criterio económico defiende que el «interés social» de una compañía mercantil, el que debe perseguir el consejo de administración, es incrementar el valor económico de la sociedad ${ }^{53}$. Sin embargo, estos cristales económicos no deben originar tanto desenfoque y hacer olvidar que el auténtico interés societario es la adecuada satisfacción de su objeto. Y, para las sociedades públicas, tal objeto se concreta en una específica finalidad de interés público, que es la que debe inspirar y conducir toda la actuación de sus órganos. No el incremento de saldo en sus cuentas o del valor económico de la sociedad. Insisto: lo verdaderamente importante es el logro público, no el lucro económico.

Por consiguiente, ya se trate de sociedades que gestionan servicios públicos, que realizan infraestructuras, que desempeñan una actividad económica de clara trascendencia social, etc., la mirada ha de estar puesta siempre en el horizonte de la mejor obtención del interés público. Toda participación pública significativa en una mercantil tinta el color del objeto societario y, en consecuencia, los representantes de las sociedades públicas deberán cuidar de que se satisfagan y protejan los servicios públicos.

Insistir en esta idea de la prioridad del interés público puede conducir a que los beneficios y dividendos soñados por el accionista privado que participa de manera minoritaria en una sociedad pública se desvanezcan y queden en malograda expectativa. Que su ilusión por intervenir en la realización de grandes infraestructuras o de incorporarse a duraderos negocios de prestación de servicios públicos se contrasten luego con las costosas inversiones, la pérdida de otras oportunidades de negocio, el mantenimiento de la continuidad de un servicio poco o nada rentable, el establecimiento de nuevas prestaciones y obligaciones en el servicio público, y otras circunstancias, de tal modo que esas iniciales ensońaciones se transformen en pesadillas preocupantes ante las pérdidas económicas y las necesidades de refinanciación.

En ámbitos estrictamente privados tales conflictos se encauzan a través de las diversas técnicas que ha construido la doctrina mercantilista para proteger a los accionistas minoritarios ${ }^{54}$. Sin embargo, cuando estamos ante una

53 Sirva, por todos los comentarios y explicaciones mercantiles de este permanente y persistente ánimo de lucro, la afirmación realizada por la Comisión que redactó el «Código de buen gobierno de las sociedades cotizadas», que perfiló el «interés social» como «el criterio que presida la actuación del Consejo sea la maximización, de forma sostenida, del valor económico de la empresa».

54 Por todos, J. M. Embid Irujo (1987), Grupos de sociedades y accionistas minoritarios. La tutela de la minoría en situaciones de dependencia societaria y grupo, Madrid: Ministerio de Justicia, que explica con claridad algunas técnicas de protección como los derechos 
sociedad pública, incluso mixta porque mantenga cierto capital privado, ha de atenderse de manera prioritaria al fin público que constituye su objeto, aunque ello no conduzca a acrecentar la bolsa de pingües beneficios o, incluso, en algún caso, se debata en medio de quebrantos y mermas económicas. En fin, hay técnicas a las que se puede recurrir. Las expuse hace años y a ellas me remito ${ }^{55}$.

\section{EL RÉGIMEN DE CONTRATACIÓN}

Otro buen ejemplo para advertir la sujeción a las reglas administrativas por las sociedades mercantiles públicas es, como bien recuerda Carmen Chinchilla, la legislación de contratación. De la inicial aspiración de las sociedades públicas de no someterse a los procedimientos públicos de contratación y negociar con la libertad de contratación propia de las empresas privadas, hace años que las sociedades públicas han de atender a conocidas previsiones de las directivas, así como a las instrucciones que sistematicen y que garanticen el respeto a los principios jurídicos públicos propios de estas actuaciones (publicidad, concurrencia, transparencia, confidencialidad, igualdad y no discriminación...). Y todo ello, como es sabido, no por una actitud voluntaria del legislador español, sino consecuencia de las sucesivas regañinas de la Comisión Europea y condenas del Tribunal de Justicia de la Unión Europea ${ }^{56}$.

Pero es más, los pasos dados en la nueva ley a la hora de extender el cumplimiento de tantas reglas clásicas "administrativas» a la contratación de las sociedades, a saber, el régimen de los pagos, la posibilidad de establecer condiciones especiales de interés público en la ejecución del contrato, las previsiones relativas a la modificación o a la cesión del contrato, las subcontrataciones y otras consecuencias, que se deducen de la lectura del art. 319 de la Ley de contratos, son razones con peso que recuerda Carmen Chinchilla para criticar con valentía su calificación como «contratos privados».

Comparto esta crítica en parte, pues siguiendo a otros autores he considerado hace tiempo que se difuminarían algunas gratuitas incongruencias y

de información, impugnación de decisiones, derechos de separación, etc. La propuesta del Código de Sociedades Mercantiles, que se presentó en 2002, establecía también el deber de compensar los perjuicios irrogados por las instrucciones de la sociedad dominante, así como el derecho de separación de los llamados socios externos.

55 Grupos públicos de sociedades, cit., págs. 157 y ss.

56 Considero que no es necesario recordar las sucesivas sentencias del Tribunal de Luxemburgo que condenaron a Espańa por incumplimiento de las sucesivas directivas europeas en el ámbito de la contratación, así como los agudos comentarios de las mismas que sirvieron para ir reformando la ley de contratos. 
disonancias a la hora de delimitar en la legislación de contratos aquellos bautizados como administrativos de los nombrados como privados ${ }^{57}$. Y me atrevía a suscitar si no sería más conveniente atraer hacia el orden jurisdiccional contencioso-administrativo los conflictos existentes. Del mismo modo que ya se hace, como hemos recordado, con relación a la exigencia de la responsabilidad patrimonial ${ }^{58}$.

Soy consciente de que esa unidad de fuero contiene otros problemas que no se deben ignorar. Por un lado, los distintos tiempos en la solución de los conflictos. Muy diferentes en unas u otras jurisdicciones. Por otro, porque tiznar toda actuación negocial de una sociedad pública con la sombra del derecho administrativo podría llegar a dificultar la necesaria agilidad que requieren muchos gestores de empresas que han tratado de evitar el peso «plomizo» de tantos trámites y actuaciones que impiden volar con flexibilidad a las sociedades. Aunque, quizás, ello ayude a impulsar los movimientos de «simplificación» administrativa y una mejora en el análisis de los procedimientos ${ }^{59}$.

En todo caso, hay que reconocer el incremento de una vis atractiva del orden contencioso-administrativo consecuencia de la reinterpretación de las normas del derecho de la Unión Europea que atienden a procedimientos de adjudicación "públicos» y, por ello, contratos «públicos» que se confunden y malequiparan con nuestros clásicos términos de contratos "administrativos».

No olvidemos que también las sociedades privadas que actúan en determinados sectores económicos de interés general han de atender, como es conocido, a un régimen de publicidad en determinados contratos. Entre otros, los que abreviamos con la fórmula de los sectores especiales del agua, la energía, los transportes y el servicio postal ${ }^{60}$.

57 Es mucha la herencia recibida de la obra de R. Parada (1961), Los orígenes del contrato administrativo en el Derecho español, Sevilla: IGO, donde ya apuntaba a las ventajas de una unidad de fuero (en especial, págs. 97 y ss.).

58 «Los problemas de la delimitación entre los contratos públicos y los privados de las Administraciones públicas», Revista de Jurisprudencia Aranzadi, 8, 2000, págs. 9 y ss.

59 En este sentido, me remito a las interesantes consideraciones de los autores que participan en la obra colectiva coordinada por E. Gamero Casado (2014), Simplificación del procedimiento administrativo y mejora de la regulación, Valencia: Tirant lo Blanch, así como a la monografía de L. A. Ballesteros Moffa (2017), La administración simplificada, Valencia: Tirant lo Blanch, en especial, págs. 171 y ss.

60 En el momento de escribir estas líneas todavía no se ha adaptado el derecho español a la nueva directiva europea, sirvan las consideraciones en este sentido realizadas con relación a la anterior directiva de J. Bermejo Vera (2008), «El régimen de contratación en los sectores especiales del agua, la energía, el transporte y los servicios postales», Revista de Administración Pública, 176, págs. 115 y ss., así como J. García-Andrade 
Unas exigencias pensadas para atender a los derechos de los ciudadanos que empiezan a conformar unas actuaciones trufadas de sabor "público» ${ }^{61}$.

Porque, hemos de admitir: nos encontramos en el dintel de una puerta que se ha abierto a la atención de otros paradigmas jurídicos. Hemos de equilibrar de nuevo en la balanza la distinción entre los principios de derecho público y privado con el fin de reconocer en todos los ámbitos los derechos fundamentales como también atender a los intereses generales y comunes de los ciudadanos. Y ello aunque estén actuando sociedades públicas o compañías privadas. Cuestión relevante que ha de ser objeto de otro trabajo. Por ello conviene ya concluir estas acotaciones.

\section{EPÍLOGO}

En resumen, a mi juicio, las sociedades públicas mantienen una personalidad jurídica propia y separada de la Administración matriz que les hace responsables de sus actuaciones y, en consecuencia, del pago de sus deudas. Sus dificultades económicas deberán analizarse con rigor para evitar que prestaciones de servicios públicos padezcan. Pero ello no ha de significar que el patrimonio público acuda presto para salvar los menoscabos y mucho menos pagar sin mayores análisis a los distintos acreedores. Si los quebrantos económicos son relevantes, podrán encauzarse soluciones mediante los instrumentos que permite el concurso de acreedores.

En todo caso, deberá siempre analizarse la responsabilidad de los administradores: cómo han gestionado el patrimonio, cómo han invertido y actuado para determinar si han incurrido en alguna responsabilidad contable o en una administración imprudente. Es más, incluso, si la Administración matriz no actúa, podrían los acreedores societarios dirigirse contra los negligentes administradores como prevé la ley mercantil.

Porque las sociedades públicas siguen siendo compañías mercantiles a pesar de tener también que atender a las reglas que inspiran el derecho públi-

Gómez (2005), Derecho administrativo en la contratación entre privados (sociedades, fundaciones, concesionarios y sectores excluidos), Madrid: Marcial Pons.

61 En este sentido recuerdo la sentencia del Supremo de 9 de marzo de 2017 (TS: 2017:842) que confirma la sanción de un millón de euros a una empresa gasística por incumplir los trámites establecidos para el corte del suministro ante un retraso en el pago. Ha tratado estas cuestiones, entre otros autores, de manera preferente D. Canals (2003), El ejercicio por particulares de funciones de autoridad (control, inspección y certificación), Granada: Comares, y M. Cueto Pérez (2008), Procedimiento administrativo, sujetos privados y funciones públicas, Madrid: Civitas. 
co: la llevanza contable de su patrimonio, las previsiones presupuestarias, la publicidad de sus contratos, los principios de mérito y capacidad para contratar personal. Y también porque no puede defraudarse el régimen administrativo por la voluntad caprichosa del gobernante.

La Administración no puede disfrazarse para eludir unos mínimos controles de interés público. Si la Administración justifica la conveniencia de crear una compañía mercantil será porque se advierte las ventajas de la flexibilidad de esa forma jurídica. Pero si reforma tras reforma, el legislador va encorsetando ese régimen jurídico de tal modo que resulte irreconocible su esencia mercantil, entonces es mejor que desaparezca la posibilidad de crear sociedades públicas. ¿Para qué tanta reproducción y multiplicación si han de seguir el tradicional régimen administrativo? A mi entender, este final carece de sentido.

Terminan aquí mis acotaciones al estudio de Carmen Chinchilla cuya lectura, como ocurre con los buenos trabajos, permite aprender por lo que ilustra y, además, abre el pensamiento a nuevas sugerencias. 
